\title{
MEDIASI PERBANKAN DALAM PENYELESAIAN SENGKETA ANTARA NASABAH DAN BANK
}

\author{
Muhammad Audi \\ St. Laksanto Utomo \\ laksanto@gmail.com \\ Universita Sahid Jakarta
}

\begin{abstract}
ABSTRAK
Sektor perbankan memiliki posisi yang strategis sebagai lembaga intermediasi. Dalam menjalakan kegiatannya, bank membutuhkan kepercayaan dari masyarakat. Oleh karenanya sudah seharusnya bank memberikan perlindungan hukum terhadap hak-hak masyarakat khususnya nasabah. Bank sebagai suatu lembaga yang menghimpun dan menyalurkan dana masyarakat dapat menimbulkan suatu hubungan hukum yang berpotensi mengakibatkan terjadinya sengketa antara nasabah dan bank. Salah satu bentuk perlindungan hukum yang dikeluarkan oleh Bank Indonesia adalah Peraturan Bank Indonesia (PBI) No 8/5/PBI/2006 tentang Mediasi Perbankan, sebagaimana telah diubah dengan PBI No 10/1/PBI/2008. Mediasi Perbankan merupakan salah satu alternatif penyelesaian sengketa untuk menyelesaikan sengketa antara nasabah dan bank. Alternatif lain yaitu dengan melalui Badan Penyelesaian Sengketa Konsumen (BPSK). Penelitian ini dilatarbelakangi oleh sejumlah pertanyaan yakni, bagaimana Mediasi Perbankan dalam penyelesaian sengketa antara nasabah dan bank? Dan bagaimana perbandingan mekanisme penyelesaian sengketa antara Badan Penyelesaian Sengketa Konsumen (BPSK) dengan Mediasi Perbankan oleh Bank Indonesia (BI)?. Untuk meneliti hal-hal tersebut digunakan metode penelitian normatif dengan pendekatan yang bersifat kualitatif.
\end{abstract}

Kata Kunci:Mediasi Perbankan; Alternatif Penyelesaian Sengketa; Badan Penyelesaian Sengketa Konsumen

\begin{abstract}
Banking sector has a strategic position as an institute of intermediation. In carrying out its activity, a bank needs the trust and support from community. Therefore, a bank should have given a protection to the rights of community especially the rights of counsumers. As an institution raising and distributing community's fund, a bank can create a legal relationship which is potential in causing a dispute between the customers and the bank. One of the legal protections produced by Bank Indonesia is Peraturan bank Indonesia (PBI) No 8/5/PBI/2006 tentang Mediasi Perbankan, has been changed with PBI No 10/1/PBI/2008. Banking Mediation is one of the an alternative
\end{abstract}


dispute resolution to solve any dispute existing between the customers and the bank. Another alternative dispute resolution is with a Badan Penyelesaian Sengketa Konsumen (BPSK). This study was initiated by a number of questions such has, how Banking Mediation in dispute resolution between the customer and the bank, and how comparison mechanism dispute resolution between Badan Penyelesaian Sengketa Konsumen (BPSK) with Banking Mediation by Bank Indonesia (BI). Based on the objectives that mention above, this research use the method of normative legal research with qualitatife approach. The instrument of collecting is library research which use primary and secondary data.

Key words: Banking Mediation; Alternative Dispute Resolution; Badan Penyelesaian Sengketa Konsumen,

\section{PENDAHULUAN}

\section{LATAR BELAKANG}

Bank menyediakan produk-produk berupa penerimaan simpanan dan pemberian kredit. Simpanan dapat ditarik nasabah setiap saat sesuai dengan kebutuhan atau kepentingan nasabah tersebut, sedangkan piutang bank hanya dapat ditagih oleh bank berdasarkan jangka waktu tertentu, sehingga apabila terjadi krisis kepercayaan, maka dapat terjadi bank tersebut kekurangan dana karena nasabah yang menarik simpanan atau tabungan mereka pada tabungan tersebut, jadi karena hal itu maka bank disebut sebagai lembaga kepercayaan.

Hubungan yang terjalin antara nasabah dengan bank didasarkan pada prinsip kepercayaan, akan tetapi pada praktiknya sangat rentan terjadi atau timbul sengketa (dispute) di antara kedua pihak. Perselisihan atau sengketa tersebut biasanya disebabkan dimana salah satu pihak tidak menjalankan kesepakatan yang telah dibuat ataupun adanya salah satu pihak yang melakukan wanprestasi, sehingga merugikan pihak lainnya. Dari berbagai pengalaman yang ada, timbulnya konflik tersebut terutama disebabkan oleh empat hal di bawah ini ${ }^{1}$ :

1. Informasi yang kurang memadai mengenai karakteristik produk atau jasa yang ditawarkan oleh bank,

2. Pemahaman nasabah terhadap aktivitas dan produk atau jasa yang masih kurang,

3. Ketimpangan hubungan antara nasabah dengan bank, khususnya bagi nasabah peminjam dana, dan

4. Tidak adanya saluran yang memadai untuk menfasilitasi penyelesaian awal friksi yang terjadi antara nasabah dengan bank.

\footnotetext{
${ }^{1}$ Muliaman D. Hadad, Perlindungan dan Pemberdayaan Nasabah Bank dalam Arsitektur Perbankan Indonesia, http://bankirnews.com/index.php?option=com_content\&view=article\&id=735:perlindungan-apemberdayaan-nasabah-dalam-arsitektur-perbankan-indonesia-api\&catid=91:api\&Itemid=139, di akses pada tanggal 17 September 2012.
}

St. Laksanto Utomo, dkk, Mediasi Perbankan Dalam Penyelesaian Sengketa 
Melihat dari empat hal tersebut maka bisa dilihat bahwa sangat mudahnya terjadi perselisihan atau sengketa antara nasabah dengan bank. Oleh karena itu harus adanya perlindungan nasabah karena sangat berpengaruh bagi nasabah, dengan demikian menjadi tantangan yang besar bagi perbankan dan Bank Indonesia untuk menciptakan standar yang jelas dalam memberikan perlindungan terhadap nasabah ${ }^{2}$.

Sengketa perbankan biasanya berawal dari keluhan-keluhan dan komplain yang diajukan nasabah kepada bank karena merasa dirugikan secara finansial. Upaya yang bisa dilakukan oleh nasabah antara lain yaitu datang langsung ke bank, menelpon call center bank tersebut, menulis surat yang berisi keluhan atau komplain nasabah secara langsung kepada bank atau menulis pada surat pembaca yang terdapat pada media cetak atau koran.

Berikut ini adalah salah satu kasus yang dimuat di harian surat kabar nasional yaitu Suara Pembaruan ${ }^{3}$ tepatnya pada kolom opini \& editorial, "saya pemilik kartu kredit Standard Chartered visa no : 4511-xxx-xxxxxx, selama kurang lebih 6 tahun saya hanya menggunakannya untuk belanja cicilan tetap. Pada tahun 2007 saya ditawari untuk balanced transfer $R p$ 1.000.000, dengan cicilan tetap 12 kali, karena tinggal satu kali cicilan lagi, pihak bank menawarkan kembali balanced transfer. Saya minta $R p$ 4.000.000, akhirnya ditransfer dua kali yaitu $R p$ 3.000.000 dan seminggu kemudian $R p$ 1.000.000, dengan iming-iming ditagih bulan berikutnya dengan bunga 1,6\% selama 24 bulan. Balanced transfer ${ }^{4}$ pertama 1 juli 2007 seharusnya sudah selesai, namun tiba-tiba muncul lagi repeat tanpa saya terima uangnya sehingga di tagihan muncul 3 tagihan ditambah bunga menjadi ada 4 transaksi yang setiap bulannya saya harus mencicil Rp 550.000. Setelah berjalan satu tahun saya baru cek, ternyata saya punya hutang fiktif yang seharusnya tahun 2008 yang Rp 1.000 .000 sudah lunas, tapi saya bayar terus dengan cicilan yang tahun 2008 berjalan. Saya mengajukan komplain ke pihak Standard Chartered bank lengkap dengan billing statement ${ }^{5}$.

\footnotetext{
${ }^{2}$ Erna Priliasari, op.cit, hlm. 43.

${ }^{3}$ Suara Pembaruan, Jum' at 17 Februari 2012

${ }^{4}$ A balance transfer is the transfer of (part of) the balance (either money or credit) in an account to another account, often held at another institution ( sebuah transfer saldo adalah transfer ( bagian dari ) keseimbangan ( baik uang atau kredit ) dalam satu akun ke akun lain, sering diadakan di lembaga lain, http://encyclopedia.thefreedictionary.com/balance+transfer, diakses pada tanggal 4 November 2012 ${ }^{5}$ billing statement is a notification sent to a customer who has been invoiced but has not yet paid. It summarizes their balance, and requests payment. Statements should be mailed a few days after the invoice is mailed, before the end of the first billing cycle (see the schedule). If payment is not received by the end of the second billing cycle, send a second billing statement, which is the first step of the collection process ( Sebuah pernyataan penagihan adalah pemberitahuan dikirim ke pelanggan yang telah ditagih tetapi belum dibayar. Ini merangkum keseimbangan mereka, dan pembayaran permintaan,
}

St. Laksanto Utomo, dkk, Mediasi Perbankan Dalam Penyelesaian Sengketa 
Pihak bank hanya menjelaskan cicilan yang diterima dan sisanya. dan setelah saya komplain sejak saat itu sampai sekarang saya tidak pernah terima billing statement lagi dan saya tidak pernah memberikan izin lewat email karena setelah saya cek lewat email pun tidak pernah ada. Setiap bulan saya minta ke Standard Chartered bank untuk minta billing statement dan pihak bank hanya menjawab akan ditindaklanjuti, namun selama satu tahun saya tidak pernah menerimanya. Saya kesal dan setelah menanyakan ke pihak bank saya lihat ada tagihan Rp 2.900.000. Saya akan melunasinya namun perhitungan bank saya harus membayar $R p$ 6.250.000. Saya tidak terima karena bank beralasan saya punya utang cicilan tetap jadi harus dihitung bunga sampai 12 bulan berikutnya. sekarang cicilan tetap saya sudah lunas, tetapi hutang saya muncul lagi Rp 2.900.000. Saya komplain lagi ke pihak bank selalu dan selalu dijawab "karena bapak bayarnya dicicil”. Saya bingung karena perjanjian awal kalau saya punya hutang cicilan tetap 24 bulan, selama ini saya bayar cicilan dengan jumlah persis yang ditagihkan, sehingga total pembayaran hutang saya yang Rp 4.000 .000 menjadi $24 x R p$ $550.000 R p$ 13.200.000, sekarang masih muncul tagihan saya $R p$ 2.900.000 lalu hutang apalagi? saya mohon pertolongan kepada yang berwenang untuk menyelesaikan permasalahan saya yang tak kunjung selesai".

Melihat pada masalah keluhan dan komplain nasabah tersebut, terkadang ada bank yang kurang memperhatikan atau bahkan mengabaikan keluhan dan komplain yang diajukan oleh nasabah, padahal bank berkewajiban untuk menanggapi dan menyelesaikan setiap pengaduan nasabah yang sebagaimana diatur dalam Peraturan Bank Indonesia No 7/7/PBI/2005 tentang Penyelesaian Pengaduan Nasabah sebagaimana telah diubah dengan Peraturan Bank Indonesia No 10/10/PBI/2008 yang diterbitkan pada tanggal 20 Januari 2005 dan telah diubah pada tanggal 28 Februari 2008.

Penyelesaian pengaduan nasabah dalam Peraturan Bank Indonesia No 7/7/PBI/2005 pada kenyataannya tidak selalu dapat memberikan solusi yang baik dan memuaskan bagi nasabah. Hal tersebut disebabkan karena pengaduan nasabah tersebut berada di dalam internal bank tersebut sehingga penyelesaiannya merupakan kebijakan bank yang bersangkutan. Jadi apabila bank tersebut telah mengeluarkan putusan maka permasalahan tersebut selesai. Akan tetapi terkadang tidak semua nasabah menerima begitu saja hasil putusan yang dikeluarkan oleh bank tersebut karena masih dianggap merugikan nasabah,

http://financial-dictionary.thefreedictionary.com/Statement+Billing, diakses pada tanggal 15 Oktober 2012

St. Laksanto Utomo, dkk, Mediasi Perbankan Dalam Penyelesaian Sengketa 
berbagai cara dapat ditempuh oleh nasabah yaitu diantaranya dengan melaporkan bank tersebut kepada pihak polisi. Melihat pada hal tersebut maka peran Bank Indonesia sangat dibutuhkan karena Bank Indonesia adalah Bank Sentral ${ }^{6}$.

Mediasi perbankan merupakan salah satu alternatif upaya untuk menyelesaikan sengketa antara nasabah dengan bank. Alternatif upaya lain selain mediasi perbankan adalah dengan melalui Badan Penyelesaian Sengketa Konsumen (BPSK) karena nasabah merupakan pengguna jasa atau konsumen dari bank, sedangkan bank merupakan penyedia jasa atau bisa dikatakan sebagai pelaku usaha dalam bidang perbankan. Akan tetapi karena kurangnya pengetahuan masyarakat mengetahui tentang keberadaan Badan Penyelesaian Sengketa Konsumen, hal ini disebabkan karena kurangnya publikasi yang dilakukan oleh Badan Penyelesaian Sengketa Konsumen ${ }^{7}$.

\section{PEMBAHASAN}

\section{A. Mediasi Perbankan Dalam Penyelesaian Sengketa Antara Nasabah Dan Bank}

Mediasi perbankan merupakan alternatif penyelesaian sengketa yang sangat diperlukan, karena sering terjadinya perselisihan antara nasabah dan bank yang menyebabkan terjadinya sengketa antara nasabah dan bank. Hal ini dapat dilihat pada tingginya kebutuhan nasabah terhadap adanya mekanisme penanganan dan penyelesaian pengaduan tercemin dari tingginya jumlah pengaduan yang diterima oleh bank. Sesuai dengan laporan perbankan yang disampaikan kepada Bank Indonesia pada tahun 2010 terdapat 683.246 pengaduan, angka ini mengalami peningkatan pada tahun 2011 menjadi 853.892 atau meningkat sebesar 25\%, sedangkan pada tahun 2012, jumlah pengaduan sampai dengan triwulan ke II telah mencapai 430.921 pengaduan $^{8}$.

Terkait dengan jumlah sengketa yang telah dimohonkan untuk diselesaikan melalui mediasi perbankan, Bank Indonesia mencatat dalam kurun waktu enam tahun terakhir sengketa perbankan antara nasabah dan bank yang diproses melalui mediasi perbankan telah mencapai 1.606 kasus, terhitung Januari 2006 hingga September 2012, adapun pada triwulan kedua 2012, terdapat 55 kasus sengketa antara nasabah dan bank yang memenuhi persyaratan untuk diselesaikan melalui mediasi perbankan Bank Indonesia, Kepala Departeman Investigasi \& Mediasi Perbankan Bank Indonesia Sri Rahayu Widodo mengatakan permasalahan yang paling banyak diajukan merupakan sengketa pada bidang sistem pembayaran

\footnotetext{
${ }^{6}$ Yang dimaksud Bank Sentral, yaitu bank yang dapat bertindak sebagai bankers, bank pimpinan, penguasa moneter, mendorong dan mengarahkan semua jenis bank yang ada.

${ }^{7}$ Heri, wawancara dengan sekretaris BPSK Provinsi Jakarta, tanggal 7 April 2012

${ }^{8}$ Pengaduan Nasabah Capai 430.921 Minimalisir Pengaduan, BI Aktif Gelar Mediasi Perbankan, http://rakyatsulsel.com/pengaduan-nasabah-perbankan-capai-430-921.html, diakses pada tanggal 18 Desember 2012.
}

St. Laksanto Utomo, dkk, Mediasi Perbankan Dalam Penyelesaian Sengketa 
kemudian sengketa di bidang penyaluran dana yang didominasi permohonan restrukturisasi kredit 9 .

Selain itu Ketua Tim Mediasi Perbankan Indonesia, Sondang Martha Samosir mengatakan bahwa jenis kasus perbankan yang sering muncul selama enam tahun berturut-turut adalah seputar sistem pembayaran (620 kasus), penyaluran dana (581 kasus), serta penghimpunan dana (190 kasus) ${ }^{10}$. Bank Indonesia menyatakan sengketa antara bank dan nasabah lebih banyak terjadi di kota-kota besar seperti Jakarta, Medan, Bandung, dan Surabaya. Dalam kota-kota besar tersebut produk-produk yang ditawarkan oleh bank biasanya lebih banyak diminati karena berbagai alasan untuk memenuhi kebutuhan serta biaya hidup pada kota-kota besar yang relatif lebih mahal dibandingkan dengan kebutuhan serta biaya hidup pada kota-kota kecil yang lebih murah.

Kehadiran mediasi perbankan sangatlah diperlukan karena mediasi perbankan diharapkan dapat menyelesaikan sengketa perdata antara nasabah dan bank jika sengketa tersebut tidak dapat diselesaikan melalui mekanisme pengaduan nasabah yang diatur dalam Peraturan Bank Indonesia No 7/7/PBI/2005 sebagaimana telah diubah dengan Peraturan Bank Indonesia No 10/10/PBI/2008 Tentang Penyelesaian Pengaduan Nasabah. Kehadiran mediasi perbankan tidak saja menguntungkan nasabah tetapi juga menguntungkan bank, hal tersebut dapat dilihat ketika ada suatu sengketa antara nasabah dan bank, nasabah yang mengajukan penyelesaian sengketa tersebut yang merasa tidak puas haruslah sesegera mungkin diselesaikan oleh bank, karena dalam pengajuan sengketa yang dilakukan oleh nasabah selain untuk kepentingan nasabah juga untuk kepentingan bank.

\section{B. Mekanisme Penyelesaian Sengketa melalui Mediasi Perbankan dan Badan Penyelesaian Sengketa Konsumen (BPSK)}

\section{Mekanisme Penyelesaian Sengketa Mediasi Perbankan}

\subsection{Persyaratan Pengajuan Penyelesaian Sengketa}

Pada Peraturan Bank Indonesia No 8/5/PBI/2006 sebagaimana telah diubah dengan Peraturan Bank Indonesia No 10/1/PBI/2008 telah diatur mengenai persyaratan pengajuan penyelesaian sengketa pada mediasi perbankan dalam pasal 8 Peraturan Bank Indonesia No 8/5/PBI/2006 sebagaimana telah diubah dengan Peraturan Bank Indonesia No 10/1/PBI/2008, persyaratan-persyaratannya yaitu :

a. Diajukan secara tertulis dengan disertai dokumen pendukung yang memadai, seperti bukti transaksi keuangan yang dilakukan nasabah.

\footnotetext{
${ }^{9}$ INDUSTRI PERBANKAN: Ada 1.606 Kasus antara nasabah dan bank, http://www.bisnis.com/articles/industri-perbankan-ada-1-dot-606-kasus-antara-nasabah-dan-bank, diakses pada tanggal 19 Desember 2012.

${ }^{10}$ BI Fokus Mediasi Kasus Perbankan, http://www.hukumonline.com/berita/baca/lt4f7c3e18704f3/bifokus-mediasi-kasus-perbankan, diakses pada tanggal 20 Desember 2012.
}

St. Laksanto Utomo, dkk, Mediasi Perbankan Dalam Penyelesaian Sengketa 
b. Pernah diajukan upaya penyelesaiannya oleh nasabah kepada bank, dibuktikan dengan bukti penerimaan pengaduan dan /atau surat hasil penyelesaian pengaduan yang dikeluarkan oleh bank.

c. Sengketa yang diajukan tidak sedang dalam proses atau belum pernah diputus oleh lembaga arbitrase atau peradilan, atau belum terdapat kesepakatan yang difasilitasi oleh lembaga mediasi lainnya, yaitu sengketa tersebut belum pernah diajukan oleh nasabah dan/atau bank kepada lembaga-lembaga arbitrase atau peradilan atau lembaga mediasi lainnya atau upaya penyelesaian sengketa pada lembagalembaga dimaksud dihentikan.

d. Sengketa yang diajukan merupakan sengketa keperdataan.

e. Sengketa yang diajukan belum pernah diproses dalam mediasi perbankan yang difasilitasi oleh Bank Indonesia. Jadi sengketa yang sudah pernah diproses pada mediasi perbankan tidak dapat diproses ulang.

f. Pengajuan penyelesaian sengketa tidak melebihi 60 hari kerja sejak tanggal surat hasil penyelesaian pengaduan yang disampaikan bank kepada nasabah.

Pelaksana fungsi mediasi perbankan dapat menolak pengajuan penyelesaian sengketa apabila salah satu syarat tersebut tidak dipenuhi oleh pihak yang ingin mengajukan penyelesaian sengketa pada mediasi perbankan.

1.2 Prosedur Dan Dokumen Pengajuan Penyelesaian Sengketa

Setelah persyaratan pengajuan penyelesaian sengketa maka langkah selanjutnya adalah prosedur dan dokumen pengajuan penyelesaian sengketa pada mediasi perbankan. Pengajuan penyelesaian sengketa pada mediasi perbankan dilakukan secara tertulis dalam format tertentu dengan menyertakan berbagai dokumen pendukung yang diperlukan. Formulir pengajuan penyelesaian sengketa pada mediasi perbankan telah disediakan di setiap kantor bank atau dapat dibuat sendiri oleh nasabah dengan berpedoman pada format tertentu. Dalam Surat Edaran Bank Indonesia (SEBI) No 8/14/DPNP menyebutkan bahwa dokumen yang harus disertakan yaitu :

a. Fotokopi surat hasil penyelesaian pengaduan yang diberikan Bank kepada Nasabah.

b. Fotokopi bukti identitas Nasabah yang masih berlaku.

c. Surat pernyataan yang ditandatangani diatas meterai yang cukup bahwa sengketa yang diajukan tidak sedang dalam proses atau telah mendapatkan keputusan dari lembaga arbitrase, peradilan, atau 
lembaga mediasi lainnya dan belum pernah diproses dalam mediasi perbankan yang difasilitasi oleh Bank Indonesia.

d. Fotokopi dokumen pendukung yang terkait dengan Sengketa yang diajukan.

e. Fotokopi surat kuasa khusus, dalam hal pengajuan penyelesaian sengketa dikuasakan.

Untuk menyampaikan pengajuan penyelesaian sengketa pada mediasi perbankan disampaikan pada Direktorat Investigasi dan Mediasi Perbankan, Bank Indonesia, Jakarta, dengan tembusan disampikan pada bank cabang setempat atau kantor pusat bank yang bersangkutan.

1.3 Tenggang Waktu Pengajuan Penyelesaian Sengketa

Dalam pasal 8 Peraturan Bank Indonesia No 8/5/PBI/2006 sebagaimana telah diubah dengan Peraturan Bank Indonesia No 10/1/PBI/2008 telah menentukan batas atau tenggang waktu pengajuan penyelesaian sengketa pada mediasi perbankan, yaitu maksimal 60 hari kerja sejak tanggal surat hasil penyelesaian sengketa diserahkan bank kepada nasabah. Jadi pengajuan penyelesaian sengketa pada mediasi perbankan dapat diterima maksimal 60 hari kerja setelah proses internal bank selesai dilakukan.

1.4 Jangka Waktu Penyelesaian Sengketa

Mengenai jangka waktu penyelesaian sengketa pada mediasi perbankan telah diatur dalam pasal 11 ayat (1) Peraturan Bank Indonesia No 8/5/PBI/2006 sebagaimana telah diubah dengan Peraturan Bank Indonesia No 10/1/PBI/2008 bahwa jangka waktu proses mediasi dilakukan maksimal 30 hari kerja terhitung sejak nasabah atau perwakilan nasabah dan bank menandatangani perjanjian mediasi, dengan ketentuan dapat diperpanjang berdasarkan kesepakatan bersama antara nasabah dengan bank. Jangka waktu mediasi tersebut dapat diperpanjang sampai dengan 30 hari kerja berikutnya berdasarkan kesepakatan bersama, hal ini di atur dalam pasal 11 ayat (2) Peraturan Bank Indonesia No 8/5/PBI/2006 sebagaimana telah diubah dengan Peraturan Bank Indonesia No 10/1/PBI/2008. Dalam hal perpanjangan waktu pelaksanaan proses mediasi perbankan dapat dilakukan sepanjang memenuhi persyaratan sebagai berikut :

a. Para pihak memiliki itikad baik dengan mematuhi aturan mediasi dan perjanjian mediasi (agreement to mediate).

b. Jangka waktu proses mediasi hampir berakhir, namun menurut penilaian mediator masih terdapat prospek untuk tercapai kesepakatan. 
Jadi jangka waktu pelaksanaan proses mediasi perbankan sampai dengan ditandatanganinya akta kesepakatan maksimal 60 hari kerja, dengan ketentuan sudah termasuk perpanjangan jangka waktu selama 30 hari kerja.

1.5 Proses Mediasi perbankan

Dalam proses mediasi perbankan terdapat beberapa langkah atau tahap yang harus dilakukan agar proses penyelesaian sengketa pada mediasi perbankan dapat berjalan lancar dan sesuai dengan yang diharapkan oleh para pihak, langkah-langkah tersebut yaitu :

a. Memanggil Para Pihak Yang Bersengketa

Sebelum penandatanganan perjanjian mediasi, pelaksana fungsi mediasi perbankan oleh Bank Indonesia akan memanggil para pihak untuk menjelaskan :

1. Tata cara pelaksanaan proses mediasi perbankan pada penyelesaian sengketa perbankan.

2. Seluk beluk isi perjanjian mediasi perbankan.

b. Membuat Dan Penandatanganan Perjanjian Mediasi

Sebelum proses mediasi dilaksanakan, maka nasabah atau perwakilan nasabah dan bank wajib membuat dan menandatangani perjanjian mediasi (agreement to mediate) yang berisi (diatur dalam pasal 9 ayat (1) Peraturan Bank Indonesia No 8/5/PBI/2006 sebagaimana telah diubah dengan Peraturan Bank Indonesia No 10/1/PBI/2008) :

1. Kesepakatan untuk memilih mediasi sebagai alternatif penyelesaian sengketa.

2. Persetujuan untuk patuh dan tunduk pada aturan mediasi yang ditetapkan oleh Bank Indonesia.

c. Sifat Proses Penyelesaian Sengketa Pada Mediasi Perbankan

Dalam Peraturan Bank Indonesia No 8/5/PBI/2006 sebagaimana telah diubah dengan Peraturan Bank Indonesia No 10/1/PBI/2008 tidak disebutkan sifat pertemuan dalam proses penyelesaian sengketa pada mediasi perbankan. Tetapi dalam SEBI No 8/14/DPNP dapat diketahui bahwa proses penyelesaian sengketa pada mediasi perbankan bersifat tertutup untuk umum, jadi pertemuan atau perundingan dalam proses mediasi perbankan bersifat rahasia, yang hanya dihadiri oleh para pihak yang terlibat dalam proses penyelesaian sengketa, yaitu nasabah, bank dan mediator.

d. Melakukan Klarifikasi Atau Meminta Penjelasan

Pada SEBI No 8/14/DPNP pelaksana fungsi mediasi perbankan yaitu Bank Indonesia dapat melakukan klarifikasi atau meminta penjelasan

St. Laksanto Utomo, dkk, Mediasi Perbankan Dalam Penyelesaian Sengketa 
kepada nasabah dan bank, baik klarifikasi secara lisan atau tertulis. Klarifikasi atau penjelasan yang dimaksud dilakukan dalam rangka meminta informasi mengenai permasalahan yang diajukan dan upaya-upaya penyelesaian yang telah dilakukan oleh bank.

e. Penyediaan Narasumber Tertentu Sesuai Dengan Keahliannya

Dalam rangka membantu proses penyelesaian sengketa pada mediasi perbankan apabila mengalami kebuntuan dalam upaya mencapai kesepakatan maka pelaksana fungsi mediasi perbankan juga membantu nasabah dan bank untuk menyediakan dan mendatangkan narasumber sesuai dengan keahliannya dan memiliki kompetensi terhadap masalah yang disengketakan. Dalam SEBI No 8/14/DPNP menegaskan bahwa bilamana nasabah dan bank berinisiatif untuk menghadirkan narasumber atau tenaga ahli, maka nasabah dan bank yang bersangkutan harus sepakat untuk menanggung biaya narasumber tersebut.

f. Mediator Bersikap Netral Dan Tidak Memihak

Dalam proses penyelesaian sengketa pada mediasi perbankan, maka seorang mediator harus bersikap netral yaitu tidak memihak salah satu pihak yang bersengketa, dan mediator berupaya membantu para pihak untuk mencapai kesepakatan.

g. Proses Penyelesaian Sengketa Pada Mediasi Perbankan Mengalami Kebuntuan

Berkenaan dengan aturan mediasi perbankan yang sebagaimana ditetapkan dalam SEBI No 8/14/DPNP, maka dalam hal proses penyelesaian sengketa yang mengalami kebuntuan, nasabah dan bank diwajibkan mengikuti tindakan-tindakan yang dilakukan mediator yaitu :

1. Menghadirkan pihak lain sebagai narasumber atau sebagai tenaga ahli untuk mendukung kelancaran mediasi.

2. Menangguhkan proses mediasi sementara dengan tidak melampaui batas waktu proses mediasi.

3. Menghentikan proses Mediasi.

h. Penyusunan Dan Penandatanganan Akta Kesepakatan

Kesepakatan yang dihasilkan dalam proses penyelesaian sengketa pada mediasi perbankan akan dituangkan dalam akta kesepakatan. Pada pasal 12 Peraturan Bank Indonesia No 8/5/PBI/2006 sebagaimana telah diubah dengan Peraturan Bank Indonesia No 10/1/PBI/2008, bahwa kesepakatan antara nasabah atau perwakilan nasabah dengan bank yang dihasilkan dari proses mediasi :

1. Dituangkan dalam akta kesepakatan. 
2. Yang ditandatangani oleh nasabah atau perwakilan nasabah dan bank.

i. Pelanjutan Upaya Penyelesaian Sengketa Melalui Arbitrase Atau Peradilan

Dengan tidak tercapainya kesepakatan dalam proses penyelesaian sengketa pada mediasi perbankan maka nasabah dan bank dapat menempuh dan melanjutkan upaya penyelesaian sengketa melalui arbitrse atau peradilan. Dalam SEBI No 8/14/DPNP dalam hal nasabah dan bank melakukan upaya lanjutan penyelesaian sengketa melalui proses arbitrase atau peradilan maka :

1. Mediator dilarang menjadi saksi.

2. Segala dokumen wajib disimpan oleh Bank Indonesia.

j. Berakhirnya Proses Mediasi Perbankan

Dalam SEBI No 8/14/DPNP berakhirnya proses mediasi perbankan berakhir karena :

1. Tercapainya kesepakatan.

2. Berakhirnya jangka waktu mediasi.

3. Terjadi kebuntuan yang mengakibatkan dihentikannya proses mediasi.

4. Nasabah menyatakan mengundurkan diri dari proses mediasi.

5. Salah satu pihak tidak mentaati perjanjian mediasi (agreement to mediate).

k. Kewajiban-Kewajiban Bank Dalam Proses Mediasi Perbankan

Pada Peraturan Bank Indonesia No 8/5/PBI/2006 sebagaimana telah diubah dengan Peraturan Bank Indonesia No 10/1/PBI/2008 dan SEBI No 8/14/DPNP terdapat kewajiban-kewajiban bank terkait dengan proses penyelesaian sengketa pada mediasi perbankan yaitu :

1. Memenuhi panggilan Bank Indonesia.

2. Menaati perjanjian mediasi perbankan.

3. Melaksanakan akta kesepakatan.

4. Mempublikasikan sarana alternatif penyelesaian sengketa di bidang perbankan.

\section{Mekanisme Penyelesaian Sengketa Badan Penyelesaian Sengketa Konsumen (BPSK)}

Persyaratan Permohonan Penyelesaian Sengketa Konsumen

Permohonan penyelesaian sengketa konsumen secara tertulis harus memuat secara benar dan lengkap mengenai (pasal 16 Kepmen No 350/MPP/Kep/12/2001) : 
a. Nama dan alamat lengkap konsumen, ahli waris atau kuasanya disertai bukti diri.

b. Nama dan alamat lengkap pelaku usaha.

c. Barang atau jasa yang diadukan.

d. Bukti perolehan (bon, kwitansi dan dokumen bukti lain).

e. Keterangan tempat, waktu dan tanggal diperoleh barang dan jasa tersebut.

f. Saksi yang mengetahui barang dan jasa tersebut diperoleh.

g. Foto-foto barang dan kegiatan pelaksanaan jasa, bila ada.

Apabila permohonan tidak memenuhi ketentuan atau persyaratan tersebut akan ketua Badan Penyelesaian Sengketa Konsumen dapat menolak permohonan penyelesaian sengketa konsumen.

Jangka Waktu Penyelesaian Sengketa

Pasal 55 Undang-Undang Perlindungan Konsumen menyebutkan bahwa Badan Penyelesaian Sengketa Konsumen wajib mengeluarkan putusan paling lambat dalam waktu 21 (dua puluh satu) hari kerja setelah gugatan diterima.

Majelis Dan Panitera

Setiap penyelesaian sengketa konsumen oleh Badan Penyelesaian Sengketa Konsumen dilakukan oleh majelis yang dibentuk berdasarkan keputusan ketua Badan Penyelesaian Sengketa Konsumen dan dibantu oleh panitera. Majelis sebagaimana dimaksud, jumlah anggotanya harus ganjil dan paling sedikit 3 orang yang mewakili unsur pemerintah, unsur konsumen, dan unsur pelaku usaha. Ketua majelis ditetapkan dari unsur pemerintah. Hal ini diatur dalam pasal 18 Kepmen No 350/MPP/Kep/12/2001.

\section{Perbandingan Mekanisme Mediasi Perbankan Dengan Badan Penyelesaian Sengketa Konsumen (BPSK)}

Perbandingan mekanisme yang kelima yaitu dalam hal proses penyelesaian sengketa, proses penyelesaian sengketa pada kedua mekanisme penyelesaian sengketa tersebut pada dasarnya sama yaitu seperti memanggil para pihak yang bersengketa, tetapi dalam proses penyelesaian sengketa selanjutnya memiliki perbedaan yaitu :

1. Dalam mediasi perbankan terdapat membuat dan penandatanganan perjanjian mediasi, yaitu para pihak sepakat memilih mediasi dan para pihak harus patuh terhadap peraturan mediasi yang dilakukan oleh Bank Indonesia. Sedangkan dalam Badan Penyelesaian Sengketa Konsumen para pihak yang bersengketa harus sepakat dalam memilih penyelesaian sengketa yaitu mediasi, arbitrse, dan konsiliasi. 
2. Dalam mediasi perbankan sifat proses penyelesaian sengketanya bersifat tertutup untuk umum. Sedangkan dalam Badan Penyelesaian Sengketa Konsumen setiap kota lain-lain sifatnya ada yang tertutup dan ada yang terbuka, kalau Badan Penyelesaian Sengketa Konsumen Provinsi Jakarta sifatnya terbuka ${ }^{11}$.

3. Dalam mediasi perbankan terdapat melakukan klarifikasi atau meminta penjelasan, yaitu meminta informasi mengenai duduk permasalahan yang diajukan. Sedangkan dalam Badan Penyelesaian Sengketa Konsumen terdapat pra sidang yaitu melihat kasus yang diajukan dan permasalahan yang ada mau atau tidak diselesaikan di Badan Penyelesaian Sengketa Konsumen.

4. Dalam mediasi perbankan terdapat penyediaan narasumber tertentu sesuai dengan keahliannya, yaitu apabila proses mediasi mengalami kebuntuan maka dapat menghadirkan narasumber sesuai dengan keahliannya. Sedangkan dalam Badan Penyelesaian Sengketa Konsumen sudah terdapat majelis yang mewakili unsur-unsur yang ada.

5. Dalam mediasi perbankan mediator bersikap netral dan tidak memihak. Sedangkan dalam Badan Penyelesaian Sengketa Konsumen terdapat majelis yang harus bersikap netral dan tidak memihak.

6. Dalam mediasi perbankan penyusunan dan penandatanganan akta kesepakatan yaitu apabila para pihak telah sepakat maka akan dituangkan dalam akta kesepakatan. Sedangkan dalam Badan Penyelesaian Sengketa Konsumen apabila para pihak sudah sepakat maka akan dibuat pelaksanaan kesepakatan yang merupakan bukti kedua belah pihak dan kemauan kedua belah pihak mengenai ganti rugi, dan setelah itu baru akan dibuat surat ketetapan Badan Penyelesaian Sengketa Konsumen.

7. Dalam mediasi perbankan apabila tidak tercapainya kesepakatan paka para pihak dapat melanjutkan upaya penyelesaian sengketa melalui arbitrase atau pengadilan. Sedangkan dalam Badan Penyelesaian Sengketa Konsumen apabila putusan Badan Penyelesaian Sengketa Konsumen sudah dikeluarkan dan salah satu pihak tidak menerima terhadap putusan tersebut maka dapat mengajukan keberatan ke Pengadilan Negeri dan apabila juga keberatan dengan putusan Pengadilan Negeri maka dapat mengajukan kasasi ke Mahkamah Agung Republik Indonesia.

8. Dalam mediasi perbankan dan Badan Penyelesaian Sengketa Konsumen berakhirnya proses mediasi perbankan pada dasarnya sama.

Melihat perbandingan mekanisme antara mediasi perbankan dengan Badan Penyelesaian Sengketa Konsumen maka terdapat beberapa hal yang

${ }^{11}$ Heri, wawancara dengan sekretaris BPSK Provinsi Jakarta, tanggal 7 April 2012 
sangat mendasar yang membedakan diantara kedua mekanisme penyelesaian sengketa tersebut yaitu :

1. Dalam mediasi perbankan terdapat nilai nominal tuntutan finansial yaitu berupa Rp 500.000.000,00. Sedangkan dalam Badan Penyelesaian Sengketa Konsumen tidak terdapat nilai nominal tuntutan, yang penting adalah adanya sengketa konsumen, jadi berapa saja nilainya maka dapat menempuh Badan Penyelesaian Sengketa Konsumen, oleh karena itu kebanyakan kasus yang ditangani oleh Badan Penyelesaian Sengketa Konsumen yaitu dari golongan menengah kebawah ${ }^{12}$.

2. Dalam mediasi perbankan proses penyelesaian sengketa tentunya melalui mediasi sebagai alternatif penyelesaian sengketa. Sedangkan dalam Badan Penyelesaian Sengketa Konsumen proses penyelesaian sengketa dapat melalui tiga cara yaitu melalui konsiliasi, mediasi dan arbitrase sebagai alternatif penyelesaian sengketa.

3. Dalam mediasi perbankan terdapat tenggang waktu pengajuan penyelesaia sengketa yaitu dalam waktu 60 hari. Sedangkan dalam Badan Penyelesaian Sengketa Konsumen tidak datur mengenai tenggang waktu pengajuan penyelesaian sengketa, dalam hal ini proses Badan Penyelesaian Sengketa Konsumen dilakukan sesegera mungkin selama para pihak tetap memilih Badan Penyelesaian Sengketa Konsumen untuk menyelesaikan sengketanya ${ }^{13}$.

\section{PENUTUP}

\section{A. Kesimpulan}

1. Bank Indonesia dalam rangka melakukan pembinaan dan pengawasan mempunyai peran yang besar dalam usaha menjamin perlindungan hak-hak nasabah agak hak-hak nasabah dapat terlindungi. Kebijakan yang dikeluarkan oleh Bank Indonesia salah satunya yaitu mengenai mediasi perbankan.

2. Penyelesaian sengketa mediasi perbankan bagi pihak bank dapat memberikan dampak positif terutama menyangkut kepercayaan masyarakat kepada bank oleh karena itu kepercayaan nasabah terhadap bank harus tetap dijaga dan dipertahankan dengan baik.

\section{B. Saran}

Adapun yang menjadi saran dari skripsi ini adalah sebagai berikut :

1. Berkaitan dengan Peraturan Bank Indonesia (PBI) ataupun Surat Edaran Bank Indonesia (SEBI) maka harus adanya sinkronisasi dengan hukum acara peradilan di Indonesia.

2. Dalam Lembaga Mediasi Perbankan Independen sebaiknya tidak hanya terdiri dari kalangan perbankan atau asosiasi perbankan saja tetapi

12 Heri, wawancara dengan sekretaris BPSK Provinsi Jakarta, tanggal 7 April 2012

${ }^{13}$ Heri, wawancara dengan sekretaris BPSK Provinsi Jakarta, tanggal 7 April 2012 
memasukan unsur-unsur lain seperti kalangan praktisi dan akademisi sehingga tidak hanya menguasai perbankan saja tetapi juga menguasai bidang atau ranah hukum dalam melihat suatu sengketa perbankan yang terjadi.

3. Oleh karena itu Badan Penyelesaian Sengketa Konsumen sebaiknya lebih meningkatkan promosi dan iklan terkait dengan kehadiran Badan Penyelesaian Sengketa Konsumen agar masyarakat mengetahui dan sadar tentang keberadaan Badan Penyelesaian Sengkera Konsumen tersebut.

\section{Daftar Pustaka}

Buku - Buku :

Abdurrasyid, Priyatna, Arbitrase \& Alternatif Penyelesaian Sengketa(Suatu Pengantar), Jakarta:PT Fikahati dan BANI, 2002

Amriani, Nuraningsih, Mediasi Alternatif Penyelesaian SengketaPerdata Di Pengadilan, Jakarta:Raja Grafindo, 2011

Ali, Zainudin, Metode Penelitian Hukum, Jakarta:Sinar Grafika, 2009

AZ, Lukman Santoso, Hak dan Kewajiban Hukum Nasabah Bank, Yogyakarta:Pustaka Yustisia, 2011

Fajar, Mukti \& Yulianto Achmad, Dualisme Penelitian Hukum Normatif \& Empiris, Yogyakarta:Pustaka Pelajar, 2010

Fuady, Munir, Hukum Perbankan Modern, Bandung:Citra Aditya Bakti, 2003

Garner, Bryan A., Black's Law Dictionary, United States of America:West Group, 1999

Hermansyah, Hukum Perbankan Nasional Indonesia, Jakarta:Kencana, 2008

Irawan,Candra, Aspek Hukum Dan Mekanisme Penyelesaian Sengketa Di Luar Pengadilan, Bandung:Mandar Maju, 2010

Kamus Indonesia - Inggris (An Indonesian - English Dictionary)

Kamus Inggris - Indonesia (An English - Indonesian Dictionary)

Kasmir, Bank Dan Lembaga Keuangan Lainnya, Jakarta:Raja Grafindo,1999

Nasution, AZ, Hukum Perlindungan Konsumen Suatu Pengantar Jakarta:Diadit Media, 2006 